\title{
The Use of Nutmeg Shell as a Lightweight Concrete Material
}

\author{
Budiman $^{1, a}$, Imran $^{2, b}$, and James WTP ${ }^{3, c}$ \\ 1,2,3 Department of Civil Engineering, State Polytechnic of Fakfak, Fakfak Regency, 98612, Indonesia \\ ${ }^{\mathrm{a}}$ budiman@polinef.id \\ bImran@polinef.id \\ cjameswtp@gmail.com
}

\begin{abstract}
Lightweight concrete is concrete that has a lighter density than concrete in general. Nutmeg shell utilization as coarse aggregate is expected to be the added material in the lightweight concrete mixture. The purpose of this study is to determine characteristics of the concrete aggregate and the compressive strength of the concrete design based on the DOE (Department of Environment) method and the SNI Standard. In this research, the use of nugmet shell was varied as follows: $10 \%$, $20 \%, 30 \%, 40 \%$ and $50 \%$ of the concrete weight. The research result shows that the amount of nugmet shell used into the concrete mixture affects the compressive strength of the concrete characteristics $\left(f_{\mathrm{ck}}{ }^{\prime}\right)$. The compressive strength of the concrete characteristics increases with the increase in the amount of nutmeg shell used in the concrete mixture. The compressie strength increases consecutively from $28.42 \mathrm{~kg} / \mathrm{cm}^{2}, 31.65 \mathrm{~kg} / \mathrm{cm}^{2}$ to $32.68 \mathrm{~kg} / \mathrm{cm}^{2}$ with the increase in the amount of nutmeg shell: $10 \%, 20 \%$ and $30 \%$. Then, it decreases into $29,09 \mathrm{~kg} / \mathrm{cm}^{2}$ and $27.38 \mathrm{~cm}^{2}$ with further increasing $40 \%$ and $50 \%$ nutmeg shell of the concrete weight. The average weight of the concrete mixture using nutmeg shell was $1202 \mathrm{~kg} / \mathrm{m}^{3}$ with the maximum compressive strength value of 3.2 MPa, thus it could be categorized as the lightweight concrete.
\end{abstract}

Keywords-- lightweight concrete, nutmeg shells, characteristics compressive strength

\section{Introduction}

SNI03-2847-2002 describes concrete as a construction material containing the mixture of Portland cement or other hydraulic cements, fine aggregate, coarse aggregate, and water. The additives that form solid mass are optional [1].

The additives are materials except the main components of concrete (water, cement, and aggregate) which are added to the concrete mixture. This aims to change one or more concrete properties whilst all in fresh condition or after hardening, for example the accelerating hardening, increasing ductility (reducing brittle properties), reducing hardening cracks, etc. [2].

The use of other materials such as natural fibers in lightweight concrete mixtures may affect the behavior of the concrete structure as a whole. The effect of this change needs to be investigated to provide accurate information regarding the behavior and capacity of the concrete from the nutmeg waste.

Fakfak Regency as an area that has abundant agricultural products has potential to provide additional natural materials. Nutmeg agricultural production reaches 4,000 tons/year, with a land area of 16,010 hectares [3]. The amount of production is comparable to the resulting nutmeg shell, if left unchecked it will become waste. Waste that is left without treatment will result in the environmental problems.

The use of nutmeg shell as an additional material in the concrete mixture has very good prospects in the future because of its abundant availability and their characteristics of being hard and light, so that if it is mixed in concrete it will reduce the weight of the concrete itself and will produce lightweight concrete.

Lightweight concrete has a lower density than normal concrete. According to [1], lightweight concrete is concrete that contains light aggregate and has a density of not more than $1900 \mathrm{~kg} / \mathrm{m}^{3}$, while according to [4], light concrete has a density between $1000-2000 \mathrm{~kg} / \mathrm{m}^{3}$.

The use of natural additives in concrete mixture has previously been studied [5], examined palm fiber and 
nutmeg shells as additives to normal concrete. The results show that the compressive strength of concrete using $0.25 \%$ palm fiber sample is $70.32 \mathrm{~kg} / \mathrm{cm}^{2}$. Moreover, the use of $0.25 \%$ and $0.50 \%$ nutmeg shell samples produces concrete with compressive strength of $80.03 \mathrm{~kg} / \mathrm{cm}^{2}$ and $86.13 \mathrm{~kg} / \mathrm{m}^{2}$, increase $16.34 \%$ and $22.26 \%$. Other previous researches examined the effect of banana fiber mixture on concrete [6], the effect of coconut shell substitution (endocarp) on concrete mixtures as fiber material for noise absorbtion [7], the manufacture of lightweight concrete from plastic added artificial aggregate [8], the effect of candlenut shells as a substitute for coarse aggregate on the mechanical properties of concrete [9].

This research use nutmeg shell as coarse aggregate for lightweight concrete. The purpose of this study is to determine the characteristics and compressive strength of concrete. The use of nutmeg shell proportion as a light aggregate material is $10 \%, 20 \%, 30 \%, 40 \%$ and $50 \%$ of the concrete volume with a test life of 3.7 and 28 days.

\section{Literature Review}

\section{a. Light Concrete}

Lightweight concrete has a density of not more than $1900 \mathrm{~kg} / \mathrm{m}^{3}$ [10] and has a compressive strength value of 0.35-6.90 Mpa while [11] provides a limitation for lightweight concrete, namely concrete with a weight below $1800 \mathrm{~kg} / \mathrm{m}^{3}$. A according to [12] lightweight concrete has a density between $1000 \mathrm{~kg} / \mathrm{m}^{3}$ and 2000 $\mathrm{kg} / \mathrm{m}^{3}$.

Types of lightweight concrete based on concrete weight and compressive strength [10] and [11] were presented in Table 1 and Table 2.

Table 1. Types of lightweight concrete [10]

\begin{tabular}{ccl}
\hline $\begin{array}{l}\text { Weight } \\
\text { concretes } \\
\left(\mathbf{k g} / \mathbf{m}^{\mathbf{3}}\right)\end{array}$ & $\begin{array}{l}\text { Compressive } \\
\text { strength } \\
\text { (MPa) }\end{array}$ & $\begin{array}{c}\text { Types lightweight } \\
\text { concretes }\end{array}$ \\
\hline $240-800$ & $0.35-6.9$ & $\begin{array}{l}\text { Low-Density } \\
\text { concretes }\end{array}$ \\
\hline $800-1440$ & $6.9-17.3$ & $\begin{array}{l}\text { Moderate Strength } \\
\text { lightweight concretes }\end{array}$ \\
\hline $1440-1900$ & $>17.3$ & $\begin{array}{l}\text { Structural lightweight } \\
\text { concretes }\end{array}$ \\
\hline
\end{tabular}

Table 2. Types of lightweight concrete by [11]

\begin{tabular}{ccl}
\hline $\begin{array}{l}\text { Weight } \\
\text { concretes } \\
\left(\mathbf{k g} / \mathbf{m}^{\mathbf{3}}\right)\end{array}$ & $\begin{array}{l}\text { Compressive } \\
\text { strength } \\
(\mathbf{M P a})\end{array}$ & $\begin{array}{c}\text { Types lightweight } \\
\text { concretes }\end{array}$ \\
\hline $1400-1800$ & $>17$ & $\begin{array}{l}\text { Structural lightweight } \\
\text { concretes }\end{array}$ \\
\hline $500-800$ & $7-14$ & Masonry concretes \\
\hline$<800$ & $0.7-7$ & Insulating concretes \\
\hline
\end{tabular}

Normal concrete is obtained by mixing Portland cement, water and aggregate, while for lightweight concrete the constituent materials are very dependent on the type of lightweight concrete. According to [13], there are 3 types of lightweight concrete, namely lightweight aggregate concrete, foam concrete and concrete without fine aggregate. The same thing was also conveyed by [14], several methods that can be used to reduce the weight of concrete include the following:

1) Making gas / air bubbles in the cement mix.

2) Using light aggregate, for example fired clay, pumice stone or artificial aggregate.

3) Making concrete without using fine aggregate grains (non-sand concrete).

Several parameters that affect the fine aggregate (sand) in determining the quality of the concrete are sludge content, moisture content, volume weight, absorption, specific gravity, fineness modulus and organic content [12].

The level of sludge is the percentage of size that passes filter No.200 according to ASTM and British Standards or 80 DIN (Germany) or standard filter hole size $=0.075 \mathrm{~mm}$. Laboratory testing is generally carried out by the washing method according to ASTM C-117 (2000 Sieve in Mineral Aggregate by Washing) Standard Test Method for Materials. Tolerance for testing the fine aggregate sludge content is $0.2 \%-6 \%$.

The water content in the aggregate is greatly influenced by the amount of water contained in the aggregate. The bigger the difference between the original aggregate weight and the aggregate weight after oven drying, the more water is contained by the aggregate and vice versa. Tolerance of testing moisture content in fine aggregate is $3 \%-5 \%$.

The volume weight is the ratio between the dry aggregate weight and its volume. The aim is to 
determine the weight of the fine aggregate. The test tolerance for fine aggregate is $1.4 \mathrm{~kg} / \mathrm{ltr}-1.9 \mathrm{~kg} / \mathrm{ltr}$.

The absorption is the percentage by weight of water that can be absorbed by the material to the weight of dry aggregate. Tolerance of testing fine aggregate $0.2 \%-2 \%$ and coarse aggregate $0.2 \%-4 \%$.

The specific gravity is the ratio between the weight of dry aggregate and the weight of distilled water whose content is the same as the aggregate content in a saturated state at a certain temperature. The test tolerance for fine aggregate is $1.6 \%-3.3 \%$.

The organic ingredients are materials contained in aggregates that can cause damage to concrete. The organic substances contained in fine aggregates generally come from destroyed plants, especially in the form of humus and organic sludge. Harmful organic substances include sugar, oil and fat. Sugar can inhibit cement binding and the development of concrete strength, while oil and grease can reduce cement binding capacity. The test tolerance for fine aggregates is less than a value of 3 .

\section{B. Compressive strength}

Reference [15] provides an understanding of the compressive strength of concrete, which is the amount of load per unit area, which causes the concrete specimen to crumble when loaded with a certain compressive force, which is generated by a compression machine.

\section{Research Methodology}

\section{A. Research Design}

The primary data collection fort his research is the result of testing of aggregate characteristics. This test consists of testing the level of sludge, moisture content, volume weight, absorption, and density, modulus of fineness and roughness modulus. After testing the characteristic the aggregate, it is continued with concrete mix design with $\mathrm{CP}$ (nutmeg shell) percentage equal to10\%, 20\%, 30\%, 40\% and 50\% to volume concrete weight by using cylinder size $15 \times 30 \mathrm{~cm}$. Concrete testing was performed after concrete immersion at age 3, 7 and 28 days. The study sample design is presented inTable1.
Table 1. Sample research design

\begin{tabular}{|l|l|c|c|}
\hline No. & $\begin{array}{l}\text { Sample of } \\
\text { concrete } \\
\text { specimen }\end{array}$ & $\begin{array}{l}\text { Percentage of } \\
\text { nutmeg shell } \\
\text { \% }\end{array}$ & $\begin{array}{l}\text { Testing } \\
\text { (days) }\end{array}$ \\
\hline 1 & 9 sample & 10 & $3,7,28$ \\
\hline 2 & 9 sample & 20 & $3,7,28$ \\
\hline 3 & 9 sample & 30 & $3,7,28$ \\
\hline 4 & 9 sample & 40 & $3,7,28$ \\
\hline 5 & 9 sample & 50 & $3,7,28$ \\
\hline$\sum$ & 54 sample & - & - \\
\hline
\end{tabular}

\section{B. Research Stage}

The stages of the research can be seen in Figure 1.

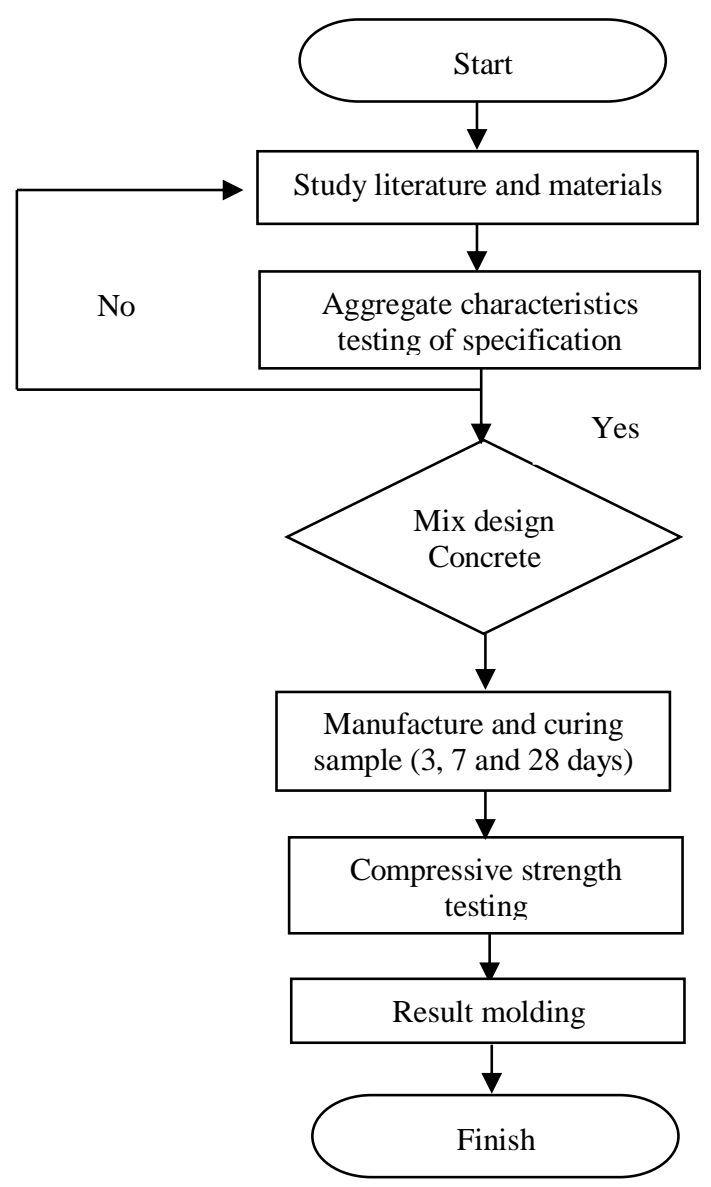

Figure 1. Flowchart of research stages

\section{Characteristic Testing}

Aggregate characteristic testing uses in this study is refered to Ref [16] as shown in Table 2. 
Table 2. Types of testing method for the concrete aggregate

\begin{tabular}{|c|l|c|}
\hline No & \multicolumn{1}{|c|}{$\begin{array}{c}\text { Types of testing } \\
\text { method }\end{array}$} & Standard \\
\hline 1 & Filter Analysis & SNI03-1968-1990 \\
\hline 2 & $\begin{array}{l}\text { Specific Weight and } \\
\text { Fine Aggregate } \\
\text { Absorption }\end{array}$ & SNI03-1970-1990 \\
\hline 3 & $\begin{array}{l}\text { Specific Weight and } \\
\text { Absorption of } \\
\text { Coarse Aggregates }\end{array}$ & SNI03-1969-1990 \\
\hline 4 & Water Content & SNI03-1971-1990 \\
\hline 5 & Volume Weight & SNI03-4804-1998 \\
\hline
\end{tabular}

\section{Compressive Strength Testing}

Compressive strength of the concrete obtained from laboratory test using compression machine were analyzed by using compressive strength equation [15]:

$$
f c=\frac{\mathrm{P}}{\mathrm{A}}
$$

where:

$$
\mathrm{fc}=\text { compressive strength }\left(\mathrm{kg} / \mathrm{cm}^{2}\right)
$$$$
\mathrm{P}=\operatorname{load}(\mathrm{kg})
$$

$\mathrm{A}=$ the weighted cross-sectional area $\left(\mathrm{cm}^{2}\right)$

\section{Results and Discussion}

The characteristics of fine aggregate (sand) resulting from laboratory tests were presented in Table 3 .

Table 3. The result of fine aggregate testing

\begin{tabular}{|c|c|c|c|c|}
\hline No & $\begin{array}{c}\text { Aggregate } \\
\text { characteristics }\end{array}$ & Interval & $\begin{array}{c}\text { Testing } \\
\text { result }\end{array}$ & Description \\
\hline 1. & Mud level & Max. 5\% & $4.00 \%$ & Qualified \\
\hline 2. & Water content & $0.5-5 \%$ & $2.33 \%$ & Qualified \\
\hline \multirow{2}{*}{3.} & Volume weight & $\begin{array}{c}1.4-1.9 \\
\mathrm{~kg} / \text { liter }\end{array}$ & 1.53 & Qualified \\
\hline 4. & Absorption & $0.2-2 \%$ & $1.01 \%$ & Qualified \\
\hline \multirow{2}{*}{5.} & \multicolumn{4}{|c}{} \\
\cline { 2 - 5 } & Specific weight \\
\cline { 2 - 5 } & Real S.W & $1.6-3.3$ & 1.737 & Qualified \\
\cline { 2 - 5 } & Dry-based S.W & 1.6 & 1.768 & Qualified \\
\cline { 2 - 5 } & Dry-surfaced S.W & 1.6 & 1.754 & Qualified \\
\hline \multirow{2}{*}{6.} & Roughness modulus & $1.50-3.80$ & 2.656 & Qualified \\
\hline
\end{tabular}

DOI : http://dx.doi.org/10.31963/intek.v7i2.2640

:
Based on table 1 on testing the characteristics of fine aggregate, the value of sludge content is $4 \%$ and contains organic content which is suitable for use. According to [12] and [17], fine aggregate should not contain more than 5\% sludge and not contain organic which can damage concrete. It is used to fill the space between coarse aggregates and provide discomfort. The modulus of fineness of 2.72 fulfills the requirements for zone 4 in the fine category. The graph of the test results for fine aggregate grains is shown in Figure 2.

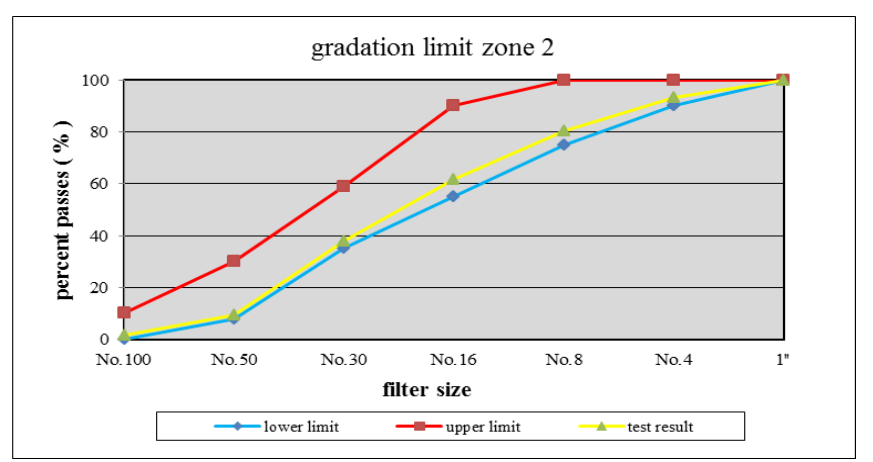

Figure 2. Graphic of fine aggregate gradation

To investigate the strength of the concrete quality that will be produced using fine aggregate (sand) and coarse aggregate from nutmeg shells is conducted by calculating the aggregate with the cement water factor $(\mathrm{W} / \mathrm{C})=0.71$ as shown in Tables 4, 5, 6, 7 and 8 .

Table 4. The results of concrete mix design with nutmeg shell $10 \%$

\begin{tabular}{|c|c|c|c|c|}
\hline $\begin{array}{c}\text { Concrete } \\
\text { material }\end{array}$ & $\begin{array}{c}\text { Weight } \\
\left(\mathrm{kg} / \mathrm{m}^{3}\right) \\
\text { the } \\
\text { amount } \\
\text { of the } \\
\text { cement } \\
(\mathrm{kg})\end{array}$ & $\begin{array}{c}\text { Weight } \\
\text { for one } \\
\text { sample } \\
(\mathrm{kg})\end{array}$ & $\begin{array}{c}\text { Weight } \\
\text { for one } \\
\text { sample } \\
(\mathrm{kg})\end{array}$ \\
\hline Water & 198.626 & 0.742 & 1.263 & 11.371 \\
\hline Cement & 267.605 & 1.000 & 1.702 & 15.321 \\
\hline Sand & 699.955 & 2.615 & 4.452 & 40.076 \\
\hline CP $10 \%$ & 21.990 & 0.082 & 0.139 & 1.259 \\
\hline$\sum$ & 1.188 & & 7.559 & 68.030 \\
\hline
\end{tabular}


Table 5. The results of concrete mix design with nutmeg shell $20 \%$

\begin{tabular}{|c|c|c|c|c|}
\hline $\begin{array}{c}\text { Concrete } \\
\text { material }\end{array}$ & $\begin{array}{c}\text { Weight } \\
\left(\mathrm{kg} / \mathrm{m}^{3}\right)\end{array}$ & $\begin{array}{c}\text { Ratio to } \\
\text { the } \\
\text { amount } \\
\text { of the } \\
\text { cement } \\
(\mathrm{kg})\end{array}$ & $\begin{array}{c}\text { Weight } \\
\text { for one } \\
\text { sample } \\
(\mathrm{kg})\end{array}$ & $\begin{array}{c}\text { Weight } \\
\text { for one } \\
\text { sample } \\
(\mathrm{kg})\end{array}$ \\
\hline Water & 198.626 & 0.742 & 1.263 & 11.371 \\
\hline Cement & 267.605 & 1.000 & 1.702 & 15.321 \\
\hline Sand & 699.955 & 2.615 & 4.452 & 40.076 \\
\hline CP 20\% & 23.32 & 0.087 & 0.148 & 1.335 \\
\hline$\Sigma$ & 1.189 & & 7.567 & 68.106 \\
\hline
\end{tabular}

Table 6. The results of concrete mix design with nutmeg shell $30 \%$

\begin{tabular}{|c|c|c|c|c|}
\hline $\begin{array}{c}\text { Concrete } \\
\text { material }\end{array}$ & $\begin{array}{c}\text { Weight } \\
\left(\mathrm{kg} / \mathrm{m}^{3}\right)\end{array}$ & $\begin{array}{c}\text { Ratio to } \\
\text { the } \\
\text { amount } \\
\text { of the } \\
\text { cement } \\
(\mathrm{kg})\end{array}$ & $\begin{array}{c}\text { Weight } \\
\text { for one } \\
\text { sample } \\
(\mathrm{kg})\end{array}$ & $\begin{array}{c}\text { Weight } \\
\text { for one } \\
\text { sample } \\
(\mathrm{kg})\end{array}$ \\
\hline Water & 198.626 & 0.742 & 1.263 & 11.371 \\
\hline Cement & 267.605 & 1.000 & 1.702 & 15.321 \\
\hline Sand & 699.955 & 2.615 & 4.452 & 40.076 \\
\hline CP 30\% & 34.98 & 0.130 & 0.222 & 2.002 \\
\hline$\sum$ & 1.201 & & 7.641 & 68.773 \\
\hline
\end{tabular}

Table 7. The results of concrete mix design with nutmeg shell $40 \%$

\begin{tabular}{|c|c|c|c|c|}
\hline $\begin{array}{c}\text { Concrete } \\
\text { material }\end{array}$ & $\begin{array}{c}\text { Weight } \\
\left(\mathrm{kg} / \mathrm{m}^{3}\right)\end{array}$ & $\begin{array}{c}\text { Ratio to } \\
\text { the } \\
\text { amount } \\
\text { of the } \\
\text { cement } \\
(\mathrm{kg})\end{array}$ & $\begin{array}{c}\text { Weight } \\
\text { for one } \\
\text { sample } \\
(\mathrm{kg})\end{array}$ & $\begin{array}{c}\text { Weight } \\
\text { for one } \\
\text { sample } \\
(\mathrm{kg})\end{array}$ \\
\hline Water & 198.626 & 0.742 & 1.263 & 11.371 \\
\hline Cement & 267.605 & 1.000 & 1.702 & 15.321 \\
\hline Sand & 699.955 & 2.615 & 4.452 & 40.076 \\
\hline CP $40 \%$ & 46.64 & 0.174 & 0.296 & 2.670 \\
\hline$\sum$ & 1.212 & & 7.716 & 69.441 \\
\hline
\end{tabular}

Table 8 . The results of concrete mix design with nutmeg shell $50 \%$

\begin{tabular}{|c|c|c|c|c|}
\hline $\begin{array}{c}\text { Concrete } \\
\text { material }\end{array}$ & $\begin{array}{c}\text { Weight } \\
\left(\mathrm{kg} / \mathrm{m}^{3}\right)\end{array}$ & $\begin{array}{c}\text { Ratio to } \\
\text { the } \\
\text { amount } \\
\text { of the } \\
\text { cement } \\
(\mathrm{kg})\end{array}$ & $\begin{array}{c}\text { Weight } \\
\text { for one } \\
\text { sample } \\
(\mathrm{kg})\end{array}$ & $\begin{array}{c}\text { Weight } \\
\text { for one } \\
\text { sample } \\
(\mathrm{kg})\end{array}$ \\
\hline Water & 198.626 & 0.742 & 1.263 & 11.371 \\
\hline Cement & 267.605 & 1.000 & 1.702 & 15.321 \\
\hline
\end{tabular}

\begin{tabular}{|c|c|c|c|c|}
\hline Sand & 699.955 & 2.615 & 4.452 & 40.076 \\
\hline $\mathrm{CP} 40 \%$ & 58.30 & 0.217 & 0.370 & 3.338 \\
\hline$\sum$ & 1.224 & & 7.790 & 70.109 \\
\hline
\end{tabular}

Based on the calculation of the results of the design above, it is obtained that the difference in weight of light concrete with $10 \%$ nutmeg shells is obtained 1,188 $\mathrm{kg} / \mathrm{m}^{3}, 20 \%$ of $1,189 \mathrm{~kg} / \mathrm{m}^{3}, 30 \%$ of $1,201 \mathrm{~kg} / \mathrm{m}^{3}, 40 \%$ of $1,212 \mathrm{~kg} / \mathrm{m}^{3}$ and $50 \%$ of $1,224 \mathrm{~kg} / \mathrm{m}^{3}$. The weight value of the concrete shows that the use of nutmeg shell on the concrete affects the weight of the concrete itself and the compressive strength value of the concrete characteristics. The results of the calculation of the mix design mixture of concrete with nutmeg shells, then analyzed the volume weight value of fresh concrete by means of the average weight of fresh concrete divided by the volume of cylindrical specimens as in Table 9.

Table 9. The weight volume of freshly concrete

\begin{tabular}{|c|c|c|}
\hline No & Sample & $\begin{array}{c}\text { Volume of Freshly } \\
\text { Concrete }\left(\mathrm{kg} / \mathrm{m}^{3}\right)\end{array}$ \\
\hline 1 & Nutmeg shell concrete $10 \%$ & 1865,6 \\
\hline 2 & Nutmeg shell concrete $20 \%$ & 1837,3 \\
\hline 3 & Nutmeg shell concrete $30 \%$ & 1792,4 \\
\hline 4 & Nutmeg shell concrete $40 \%$ & 1780,2 \\
\hline 5 & Nutmeg shell concrete $50 \%$ & 1774,8 \\
\hline
\end{tabular}

Based on table 9, the weight of nutmeg shell concrete for $10 \%$ is $1865.6\left(\mathrm{~kg} / \mathrm{m}^{3}\right)$ while for $50 \%$ it is obtained $1774.8\left(\mathrm{~kg} / \mathrm{m}^{3}\right)$, a decrease of $4.86 \%$. The greater the percentage value of nutmeg shells used in the lightweight concrete design mix, the lighter the volume weight of the fresh concrete. This shows that the use of nutmeg shells has an effect on the weight of the concrete itself.

Based on the results of the analysis of the test value of the compressive strength of concrete using nutmeg shells at the age of 28 days, it shows that light concrete with the use of nutmeg shells as coarse aggregate in the concrete mixture affects the compressive strength of the concrete characteristics (fck'). The compressive strength values for the characteristics of concrete at a composition of $10 \%, 20 \%$ and $30 \%$ were obtained at $28.42 \mathrm{~kg} / \mathrm{cm}^{2}, 31.65 \mathrm{~kg} / \mathrm{cm}^{2}$ and $32.68 \mathrm{~kg} / \mathrm{cm}^{2}$ which increased while the use of nutmeg shells at $40 \%$ and $50 \%$ compositions was obtained. The values of 29.09 
$\mathrm{kg} / \mathrm{cm}^{2}$ and $27.38 \mathrm{~kg} / \mathrm{cm}^{2}$ decreased at the age of 28 days as in Table 10.

Table 10. The value of Compressive Strength Characteristics of Concrete

\begin{tabular}{|c|c|c|}
\hline No & Sample & Value f'c $\left(\mathrm{kg} / \mathrm{cm}^{2}\right)$ \\
\hline 1 & Nutmeg shell concrete $10 \%$ & 28.42 \\
\hline 2 & Nutmeg shell concrete $20 \%$ & 31.65 \\
\hline 3 & Nutmeg shell concrete 30\% & 32.68 \\
\hline 4 & Nutmeg shell concrete $40 \%$ & 29.09 \\
\hline 5 & Nutmeg shell concrete 50\% & 27.38 \\
\hline
\end{tabular}

Based on table 10, there was an increase in the value of the compressive strength of concrete (fck ') at the composition of $20 \%$ and $30 \%$ of $10.20 \%$ and $13.03 \%$ and began to decrease in the composition of $50 \%$ by $3.65 \%$. The decrease in the compressive strength value is influenced by the higher percentage of nutmeg shells that are used in the concrete mix, thereby reducing the volume of concrete that should be filled with cement paste.

The increase in the value of the compressive strength of concrete (fck') occurred starting at the composition of $20 \%$ and $30 \%$ at $10.20 \%$ and $13.03 \%$ and begin to decrease at the composition of $50 \%$ by $3.65 \%$. The decrease in the compressive strength value is influenced by the higher percentage of nutmeg shells that are used in the concrete mix, thereby reducing the volume of concrete that should be filled with cement paste.

Lightweight concrete according to [12] and [13] is concrete with a concrete weight below $1860 \mathrm{~kg} / \mathrm{m}^{3}$ with types of lightweight concrete consisting of structural, lightweight and very light structural concrete. Lightweight concrete from nutmeg shells has an average weight of $1202 \mathrm{~kg} / \mathrm{m}^{3}$ and a maximum compressive strength value of $3.2 \mathrm{MPa}$ so that the concrete is in the lightweight structure category.

According to Ref [10] and [11] lightweight concrete with low density has a concrete weight of $240 \mathrm{~kg} / \mathrm{m}^{3}$ $800 \mathrm{~kg} / \mathrm{m}^{3}$ with a compressive strength value of $0.35-6.90$ Mpa. The range of compressive strength values, lightweight concrete from nutmeg shell is included in the lightweight concrete category with low density, so it can be concluded that nutmeg shell has the opportunity to be used as a building material for lightweight concrete. To get the right composition for its use, it is necessary to carry out further studies both for lightweight concrete and for normal concrete.

\section{Conclusion}

Some points can be concluded from this research as follows:

1. The use of nutmeg shell makes the concrete mixture lighter, the lightweight concrete, and contributes to increase the compressie strength of the concrete when using the nutmeg shell till $30 \%$ of the concrete weight.

2. The compressive strength of the lightweight concrete decreases when increasing the use of nutmeg shell more than $30 \%$ of the concrete weight.

Research suggestions and recommendations are as follows:

1. Further research is needed in determining the appropriate composition for both lightweight concrete and normal concrete

2. Further research is needed using a smaller percentage interval

3. It is recommended to use nutmeg shell as coarse aggregate in light concrete with a low density scale and intended for light structures, besides saving costs, it can also reduce waste that has an impact on the environment.

\section{Acknowledgement}

Authors would like to thank the research and innovation agency, deputy for research and development strengthening with research funding assistance and for the facility of Department of Civil Engineering.

\section{References}

[1] National Standard Agency, "Procedures for calculating concrete structures for buildings", Technical Committee for Standardization of Construction and Building, Bandung. SK SNI 03-2847-2002. 2002.

[2] Tjokrodimuljo, K., "Concrete Technology", Nafiri Publisher, Yogyakarta. 2007.

[3] Anonymous, "Fakfak Regency in Figures". Central Bureau of Statistics of Fakfak Regency. 2017. 
[4] Tjokrodimuljo, K., "Concrete Technology", Nafiri Publisher, Yogyakarta. 2003.

[5] Budiman, "The use of palm fiber and LCP as natural additives to concrete". Journal of Inovtek, Vol. 9 No. 2, 239-244. 2019

[6] Sheila Hani and Rini, "Effect of banana fiber mixture on concrete". Journal of Education Building, Vol. 4, No. 1, 40-45. 2018.

[7] Eka D. and Karolina R., "The effect of coconut shell substitution (endocarp) on the concrete mixture as a sound absorbing fiber material" Jurnal Teknik Sipil USU, Vol. 2 No. 2. 2013.

[8] Erwin Romel., "Making lightweight concrete from plastic additive artificial aggregate". Gamma Journal, Vol. 9, No. 1 137-147. 2013.

[9] Erniati B., "Effect of candlenut shell as a substitute for coarse aggregate on the mechanical properties of concrete". Department of Civil Engineering. Fajar University. 2018.

[10] Dobrowolski, A.J., "Concrete Construction Handbook", The Mc. Graw Hill Companies, Inc., New York. 1998.

[11] Neville, A.M. and Brooks, J. J., "Concrete Technology". John Willey \& Sons, New York. 1987.
[12] National Standard Agency. "Procedure for C Light Concrete Mixing with Light Aggregate". SNI 03-3449-2002. Jakarta, National Standard Agency. 2002.

[13] Raju, K. N., "Design of Concrete Mixes", CBS Publishers \& Distributors, 485, Jain Bhawan, Bhola Nath Nagar Shandra, Delhi. 1983.

[14] Tjokrodimuljo K., "Concrete Technology", Department of Civil Engineering, Faculty of Civil Engineering, Gajah Mada University. 1996.

[15] National Standardization Body. "Concrete Compressive Strength”. SK SNI 03-1974-1990. 1990.

[16] Attamimi, A., "Comparison of the compressive strength of concrete using sea sand and river sand to the compressive strength of the K-250 concrete". Final Report of the Civil Engineering Study Program at the State Polytechnic of Fakfak. Fakfak. 2015.

[17] Mulyono, T. “Concrete Technology”. Yogyakarta: Andi Offset. 2005. 